\title{
THE EFFECT OF MASSAGE AND ACTIVE STRETCHING ON SPEEDING UP BLOOD LACTIC ACID RECOVERY
}

\author{
Mimi Haetami1, Andika Triansyah ${ }^{2}$ \\ Universitas Tanjungpura, Pontianak ${ }^{1,2}$ \\ mimi.haetami@fkip.untan.ac.id ${ }^{1}$, andika.triansyah@fkip.untan.ac.id ${ }^{2}$
}

\begin{abstract}
The accumulation of blood lactic acid after high intensity activities is an acute effect that can contribute to fatigue for sportsmen, therefore it is necessary to do engineering to accelerate recovery. The purpose of this study was to determine the effect of massage and active stretching on the acceleration of blood lactic acid recovery. The research method used in this study is experimental. The research sample was 14 Physical Education students with the same subject design (within subject design) using the time difference between treatments for six days (washed out period). The data taken were blood lactic acid data before and after the engineering of recovery after the sample carried out highintensity (anaerobic) activity in this study used the form of 30-50 meter interval running activities, then to accelerate the recovery of blood lactic acid after the sample did the activity, namely the recovery technique. massage and active stretching for 5 minutes. The first recovery technique is massage (shaking and tapotement) and the second recovery technique uses active stretching. The results of the first study, the data obtained from the calculation of Sig. 2-tailed $(0,000)<0.05$, meaning that there is an effect of massage on the acceleration of blood lactic acid recovery, both asym.sig. 2-tailed (0.002) <0.05, meaning that there is an effect of active stretching on the acceleration of blood lactic acid recovery, the three asym.sig. 2-tailed (0.382)>0.05 means that there is no difference in the effect between massage and active stretching on the acceleration of lactic acid recovery.
\end{abstract}

Keywords: massage, active stretching, blood lactic acid

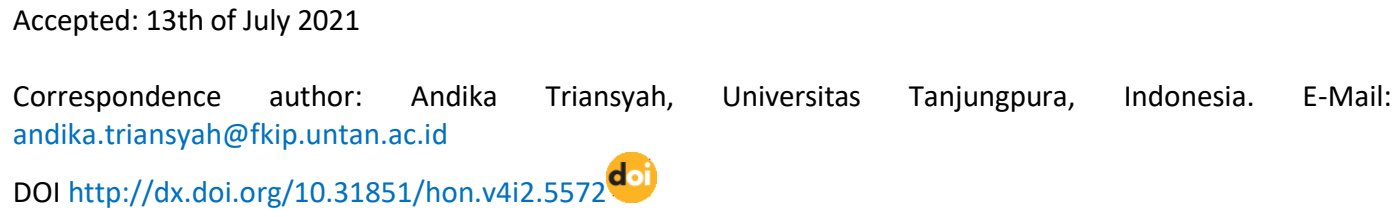

\section{INTRODUCTION}

The role of exercise physiology as a scientific study that supports athletes towards achievement must be optimized, through studies conducted by exercises that have a direct impact on athletes such as fatigue and overtraining can be managed properly so that the purpose of training to improve achievement can be 
achieved, in addition to information from the physiology of athletes can be used as the basis for the preparation of an appropriate exercise program (Anggriawan, 2015). Programmed training must meet the principles of proper training in order to meet the impact of training (overcompensation) so that the physical quality of athletes from time to time is increasing (Bazyler, Abbott, Bellon, Taber, \& Stone, 2015; Sukadiyanto \& Muluk, 2011).

Sport has an important role in the quality of one's body, exercise with regular and measurable principles is an important part of the exercise program (Arisman \& Noviarini, 2021; Syamsudin, Herawati, Qurnianingsih, \& Wungu, 2021). Exercise can cause fatigue, several previous studies have examined the impact of exercise on the emergence of fatigue, such as a study conducted by (Balk \& de Jonge, 2021) revealed that high demands for physical and emotional activity during exercise were associated with physical fatigue after exercise and competition. High physical fatigue interferes with lower physical and cognitive abilities. These findings lead to the "under-recovery trap" which means that high levels of physical exhaustion can interfere with the physical and mental recovery of athletes. Fatigue develops during football matches and is a potential physiological mechanism that causes fatigue in soccer (Okilanda et al., 2021). According to motion analysis timing and performance measures over the course of the game, fatigue and performance decline appears to occur at three distinct stages in the game: (1) after a short-term intensity period, the second half; (2) the start of the second half, and (3) towards the end of the match. From the above study, it can be seen that fatigue contributes to a decrease in the physical and cognitive performance of athletes, if this occurs in competition then it interferes with performance.

Continuous physical exercise causes a reduced capacity of the body to produce strength that usually lasts longer than regular exercise. Fatigue can be caused by impaired muscle function and decreased capacity of the central nervous system to activate muscles (Carroll, Taylor, \& Gandevia, 2017). (Rusdiana, 2020) conducted a study on the effect of fatigue on badminton athletes which, that the 
speed of the shuttlecock during the jumping smash of badminton athletes in nonfatigued conditions was faster than during fatigue. This is due to muscle fatigue that occurs after the muscle contracts strongly and for a long time so that there are times when the muscle is unable to contract at a certain time. During exercise, the working muscles produce lactic acid, anaerobic physical exercise with short duration and high intensity using an energy system derived from creatine phosphate and glycogen, lactate is the end product of anaerobic metabolism (Flora, 2015). Exercises performed with high-intensity cause fatigue, one of which is the buildup of blood lactic acid.

The relationship between lactate and physical exercise has been proven in various studies, (Beneke, Leithäuser, \& Ochentel, 2011) Blood lactate concentrations are sensitive to changes in exercise intensity and duration. Three intensity domains oriented towards blood lactate; first, high-intensity exercise that results in a buildup of blood lactate during a short rest period, or light-moderateintensity training focusing on active regeneration or high-volume endurance training (intensity < threshold); both maximal endurance training at work levels up to the maximal lactate steady state (MLSS) level (threshold intensity MLSS); the three exercises with a heavy intensity between maximal lactate steady-state and maximum oxygen uptake intensity, mostly in interval and tempo training (intensity > MLSS). The concentration of blood lactate in the muscle bloodstream, which is a product of metabolism, can lead to muscle fatigue (Ishii \& Nishida, 2013). The results of the above study indicate that high blood lactate concentrations in muscles will decrease muscle performance or may cause fatigue. Therefore, it is important to conduct further studies related to blood lactic acid in the performance of exercise and the efforts made to restore high blood lactic acid levels after exercise.

The effect of blood lactic acid on the body after doing high-intensity exercise occurs when the recovery time required is longer so that the body is not able to work optimally and if it is forced to continue to do high-intensity activities, cramps or even muscle injuries can occur. detrimental threat to athletes. 
The theory of lactate-induced acidosis states that under hypoxic conditions, such as anaerobic exercise, there is increased dissociation of lactic acid into lactate ions and hydrogen $(\mathrm{H}+)$ entering skeletal myocytes. This process induces acidosis, disrupts the cross-bridge cycle, and impairs the contractile ability of the cell (Debold, 2012). (Gorostiaga et al., 2012) menunjukkan bahwa setelah latihan, titik kritis laktat berada pada 10-15 mmol per kg-1 otot basah setelah latihan leg-press berulang yang berarti laktat terlibat dalam kelelahan otot.

The buildup of lactic acid in muscle cells can result in a decrease in muscle $\mathrm{pH}$ as well as in the blood, thus causing the work of enzymes and chemical reactions in muscle cells to be inhibited. This can cause muscle contractions to weaken and in the end, you will experience muscle fatigue (Suharjana, 2013). During recovery, lactic acid from anaerobic glycolysis will be transferred to the less active muscles of the body and to the liver to be converted into pyruvic acid. The next process is pyruvic acid is converted into glucose and then enters the bloodstream to be sent to active muscles, and can be used as an energy source for activities. (Giriwijoyo, 2017).

Sport massage is an action that will be given is believed to have a contribution to encourage faster recovery of lactic acid in a stable condition after athletes perform high-intensity activities. Massage that is engineered (artificial) or assisted, the purpose of which is to speed up recovery, in this study what is meant by recovery is obtaining a normal homeostatic condition of blood lactic acid. In addition, another form of engineering used is stretching which is routinely done by athletes after training. Based on previous studies, fatigue can occur due to the accumulation of metabolic waste (lactic acid) as a result of doing strenuous and long-lasting exercise. The accumulation of lactic acid occurs in the muscle tissue of athletes, if this occurs during competition, it is very important to make engineering efforts to accelerate recovery with this condition, it is necessary to know the effect of massage and active stretching on the acceleration of blood lactic acid recovery. 


\section{METHOD}

The research was conducted using a quantitative approach with the type of experimental research. The selected independent variables were massage and stretching with the dependent variable being the recovery of blood lactic acid. The research was conducted in Pontianak. West Kalimantan. Implementation time from 08.00 - 10.00 WIB. The research sample was Physical Education students totaling 14 people with the same subject design (within-subject design) using the time difference between treatments for six days (washed out period). This is to ensure that the effect of treatment on blood lactic acid recovery occurs due to the effect of different treatments and not due to the biological variability of the sample.

The data taken were blood lactic acid data before and after the recovery engineering was given after the sample did high-intensity (anaerobic) activity. In this study, a 30-50 meter interval running activity was used, then to accelerate the recovery of blood lactic acid after the sample did the activity, namely the recovery technique. massage and active stretching for 5 minutes. The massage technique used is shaking and tapotement and the second recovery technique uses active stretching. To measure blood lactic acid, a lactotest with the Accutrend Plus brand was used and the BM-Lactate test strip was used.

There are 3 hypotheses in this study, the data analysis used to answer the first hypothesis is the paired sample t-test, the second hypothesis is the nonparametric test (Wilcoxon test), and to find the difference between the two recovery techniques, the non-parametric test (Mann-Whitney test) is used. . Furthermore, the calculation uses the IBM SPSS Statistics 20 application. To meet the calculation assumptions, a prerequisite test for normality test analysis is carried out using Shapiro-Wilk with the criteria if the $\mathrm{p}$ value> 0.05 then the data is normal and the homogeneity test uses the Test of Homogenety of Variance with the acceptance criteria $\mathrm{p}>0.05$ then homogeneous data. 


\section{RESULTS AND DISCUSSION}

The results are described based on the number of samples $(\mathrm{N})$ used, the average calculation and standard deviation (SD) of the massage recovery technique and active stretching, the complete calculation data can be seen in table 1, below:

Table 1. Description of the analysis of massage and active stretching (AS) on the acceleration of blood lactic acid recovery.

\begin{tabular}{lccccc}
\hline \multirow{2}{*}{ Recovery } & \multirow{2}{*}{$\mathrm{N}$} & \multicolumn{2}{c}{ Pretest } & \multicolumn{2}{c}{ Posttes } \\
\cline { 3 - 6 } & & Mean & SD & Mean & SD \\
\hline Massage & 14 & 10,90 & 2,22 & 8,37 & 1,67 \\
AS & 14 & 10,58 & 2,81 & 8,38 & 2,84
\end{tabular}

Furthermore, to complete the description of the data, a diagram of the analysis of massage and active stretching is shown to accelerate the recovery of lactic acid.

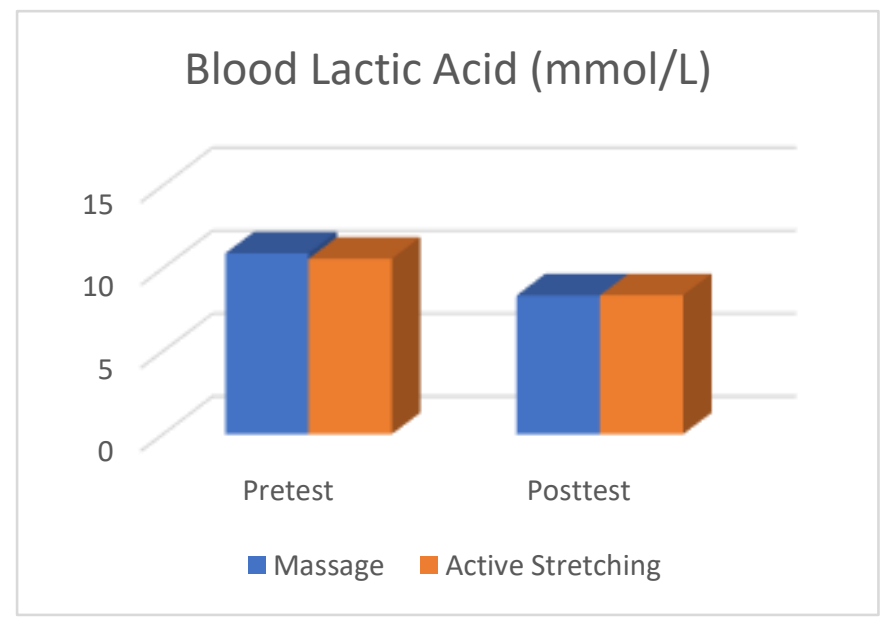

Figure 1. The average pretest and posttest of blood lactic acid concentration after being given a massage and active stretching for 5 minutes

\section{Normality test}

To find out whether the data is normally distributed or not, the ShapiroWilk test is used with acceptance criteria if the value is $p>0.05$, then the data is normally distributed, otherwise if $\mathrm{p}<0.05$, then the data is not normally distributed . More complete calculation results are in table 2 below: 
Table 2. Normality test results with Shapiro-Wilk

\begin{tabular}{cccc}
\hline Variable X & Significance & Information & Results \\
\hline Massage Pretest & 0,756 & $\mathrm{P}>0,05$ & Normal \\
Massage Posttest & 0,400 & $\mathrm{P}>0,05$ & Normal \\
AS Pretest & 0,052 & $\mathrm{P}>0,05$ & Normal \\
AS Posttest & 0,020 & $\mathrm{P}<0,05$ & Abnormal \\
\hline
\end{tabular}

\section{Homogeneity Test}

The homogeneity test of the data used is the test of homogeneity of variance, while the acceptance criteria if the value is $p>0.05$, then the data is homogeneous on the contrary if $p<0.05$, then the data is not homogeneous. More complete results obtained are in table 3 below:

Table 3. The results of the analysis of the test of homogeneity of variance

\begin{tabular}{cccc}
\hline Variable X & Significance & Information & Results \\
\hline Blood Lactic Acid & 0,208 & $\mathrm{P}>0,05$ & Homogen \\
\hline
\end{tabular}

\section{Hypothesis testing}

Hypothesis test 1 . Ha: There is an effect of massage on the acceleration of blood lactic acid recovery. H0: There is no effect of massage on the acceleration of blood lactic acid recovery. Based on the calculation of the normality of the data with normal distribution, then to test hypothesis 1 , the paired sample t-test is used. The complete data is shown in table 4 below:

Table 4. Hypothesis testing 1

\begin{tabular}{|c|c|c|c|c|c|c|c|c|}
\hline \multirow{3}{*}{$\begin{array}{l}\text { Variable } \\
\text { X1 } \\
\text { Massage }\end{array}$} & \multicolumn{5}{|c|}{ Paired Differences } & \multirow[t]{3}{*}{$\mathrm{t}$} & \multirow[t]{3}{*}{ df } & \multirow{3}{*}{$\begin{array}{l}\text { Sig. (2- } \\
\text { tailed) }\end{array}$} \\
\hline & Mean & Std. & $\begin{array}{l}\text { Std. } \\
\text { Error }\end{array}$ & $\begin{array}{r}95 \\
\text { Confi }\end{array}$ & $\begin{array}{l}\% \\
\text { lence }\end{array}$ & & & \\
\hline & & Deviation & Mean & Lower & Upper & & & \\
\hline $\begin{array}{l}\text { pretest - } \\
\text { posttest }\end{array}$ & 2.52 & 2.02 & 0.53 & 1.35 & 3.68 & 4.67 & 13 & 0.000 \\
\hline
\end{tabular}

Based on the criteria of decision-makers if the value of Sig. (2-tailed) < 0.05 , then $\mathrm{H} 0$ is rejected and $\mathrm{Ha}$ is accepted. This means that there is an effect of massage on accelerating the recovery of blood lactic acid. 


\section{OLATRAGA}

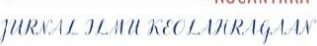

Jendral A. Yani Street Lorong Gotong Royong 9/10 U1u Palembang South Sumatera

Accredited

email jurnal: jurnalhon@univpgri-palembang.ac.id situs web: http://www.univpgri-palembang.ac.id

Hypothesis Test 2. Ha: There is an effect of active stretching on the acceleration of blood lactic acid recovery. H0: There is no effect of active stretching on the acceleration of blood lactic acid recovery. Based on the calculation of normality, there is one data that is not normally distributed, so to test hypothesis 2 , it is followed by a non-parametric test (Wilcoxon test) the complete data is in table 5 below:

Table 5. Hypothesis testing 2

\begin{tabular}{lc}
\hline $\begin{array}{l}\text { Variable X2 } \\
\text { Stretching }\end{array}$ & $\begin{array}{c}\text { posttest- } \\
\text { pretest }\end{array}$ \\
\hline $\mathrm{Z}$ & $-3.078^{\mathrm{b}}$ \\
$\begin{array}{l}\text { Asymp. Sig. (2- } \\
\text { tailed) }\end{array}$ & .002 \\
\hline
\end{tabular}

Based on the decision-making criteria if the value of Asym.Sig. (2-tailed) $<0.05$, then $\mathrm{Ha}$ is accepted. This means that there is an active stretching effect on the acceleration of blood lactic acid recovery.

Hypothesis Test 3. Ha: There is a significant difference between massage and active stretching on the acceleration of blood lactic acid recovery. H0: There is no significant difference between massage and active stretching on the acceleration of blood lactic acid recovery. To find out whether there is a significant difference between massage and active stretching on the acceleration of blood lactic acid recovery, the non-parametric Mann-Whitney test was used. This non-parametric test was chosen because there is data that is not normally distributed in one of the variables. table 6 below:

Table 6. Hypothesis testing 3

\begin{tabular}{lc}
\hline & Blood_Lactit_Acid \\
\hline Mann-Whitney U & 79.000 \\
Wilcoxon W & 184.000 \\
Z & -.874 \\
Asymp. Sig. (2-tailed) & .382 \\
Exact Sig. [2*(1-tailed & $.401^{\mathrm{b}}$ \\
Sig.)] & \\
\hline
\end{tabular}


Based on the decision-making criteria in the analysis of the Mann-Whitney test, if the value of Asym.Sig. (2-tailed) $>0.05$ Then $\mathrm{Ha}$ is rejected and $\mathrm{H} 0$ is accepted. This means that there is no significant difference between massage and active stretching on the acceleration of blood lactic acid recovery.

\section{DISCUSSION}

In the research results, there are three research hypotheses that have been proven. The results of the first hypothesis were answered with the conclusion that there was an effect of massage on the acceleration of blood lactic acid recovery, with an average pretest of $10.90 \mathrm{mmol} / \mathrm{L}$ and an average posttest of $8.37 \mathrm{mmol} / \mathrm{L}$, which means a decrease in blood lactic acid levels before and after treatment. of $2.53 \mathrm{mmol} / \mathrm{L}$. The massage technique chosen to be given as an effort to engineer the acceleration of blood lactic acid recovery is the shaking and tapotement technique, with this technique the accumulation of metabolic products (blood lactic acid) can be broken down which then the blood lactic acid can be reused as an energy source through the Cori cycle. Sport massage is able to reduce or remove lactic acid from the muscles being trained, causing damage to the muscle tissue mechanism that results in the buildup of lactic acid, the elimination of lactic acid has an impact on recovery for the body. (Wiltshire et al., 2010). The results of this study are in line with previous research conducted by (Rasooli, Jahromi, \& Salesi, 2012) The results showed that massage was able to reduce the buildup of blood lactic acid in elite swimming athletes which in turn also had an impact on appearance. The decrease in lactic acid levels as a result of massage intervention can be caused by increased blood flow which facilitates the faster flow of lactic acid to be used as an energy source in other organs (Giriwijoyo, 2017). Like the research done (Hendra Hasibuan \& H. Jutalo, 2020) about the effect of sport massage on reducing lactic acid levels resulting in recovery with sport massage can reduce body lactic acid levels by $62 \%$.

The massage technique used in this study was limited to shaking and tapotement techniques for 5 minutes in the lower extremities (muscles in the legs). Although massage has been proven to have an effect on accelerating the recovery 
of lactic acid, the final result of measuring blood lactic acid levels (posttest massage data table 1) shows that the accumulation of blood lactic acid is still high, namely $8.37 \mathrm{mmol} / \mathrm{L}$ when compared to the stable or normal state of well-trained individuals. blood lactic acid is at $0.5-2.2 \mathrm{mmol} / \mathrm{L}$ (Kaya et al., 2013). So that further research is needed with different techniques and a longer duration.

The second hypothesis in this study proved that there was an effect of active stretching on the acceleration of blood lactic acid recovery. In table 1 there is a decrease in blood lactic acid levels from before treatment by an average of $10.58 \mathrm{mmol} / \mathrm{L}$ to $8.38 \mathrm{mmol} / \mathrm{L}$ after intervention with active stretching for 5 minutes, meaning that there is a decrease in blood lactic acid by $2.2 \mathrm{mmol} / \mathrm{L}$. L. In previous studies, there were several studies linking stretching as a step to restore muscle performance and also blood lactic acid levels. (Jougla, Micallef, \& Mottet, 2010) stated that after active and passive recovery were carried out, rugby athletes showed better performance during the test, but clearly it is not recommended that passive players during the rest period, the players should move to maintain optimal condition. For energy recovery after a short active recovery, less oxygen is available to restore myoglobin and hemoglobin, remove lactic acid concentrations and resynthesize phosphocreatine. Consequently, intermittent running with a short recovery time passive recovery will cause longer fatigue when compared to active recovery. (Ningsih \& Puspitaningrum, 2018) the difference in effectiveness between active stretching and passive stretching in restoring blood lactic acid and heart rate after $400 \mathrm{~m}$ exercise resulted in better active stretching in lowering blood lactic acid. In this study, although it is proven that active stretching has an effect on accelerating the recovery of lactic acid, the posttest data in table 1 shows that the blood lactic acid content is still relatively high, which is at an average of $8.38 \mathrm{mmol} / \mathrm{L}$.

In the third hypothesis, table 6 produces an answer that there is no significant difference between massage and active stretching on the acceleration of blood lactic acid recovery. This can be seen from the average rate of reducing lactic acid levels, which are relatively the same, ranging from 2.2 to $2.5 \mathrm{mmol} / \mathrm{L}$. Furthermore, massage or active stretching for 5 minutes is proven from the results 
of posttest measurements that have not been able to reduce blood lactic acid levels in a stable or normal position, which is between $0.5-2.2 \mathrm{mmol} / \mathrm{L}$ (Kaya et al., 2013; Todd, 2014). Based on the results of the research that has been carried out, it is necessary to do further research by providing massage interventions with different techniques and different stretching to determine the acceleration of blood lactic acid recovery during a short recovery period..

\section{CONCLUSION}

The conclusions from the results of this study are first, there is the effect of massage on the acceleration of blood lactic acid recovery, second, there is the effect of active stretching on the acceleration of blood lactic acid recovery, third there is no difference in the effect of massage and active stretching on the acceleration of lactic acid recovery in physical education students after 30-50 meter interval run. However, the two interventions carried out for 5 minutes were not able to accelerate the recovery of blood lactic acid to the normal condition category.

\section{REFERENCES}

Anggriawan, N. (2015). Peran Fisiologi Olahraga Dalam Menunjang Prestasi. Jurnal Olahraga Prestasi, 11(2), 114694. Retrieved from https://doi.org/10.21831/jorpres.v11i2.5724

Arisman, A., \& Noviarini, T. (2021). Tabata Workout dalam Meningkatkan Kebugaran Atlet Panahan. Halaman Olahraga Nusantara (Jurnal Ilmu Keolahragaan), 4(1), 12-22.

Balk, Y. A., \& de Jonge, J. (2021). The "underrecovery trap": When physical fatigue impairs the physical and mental recovery process. Sport, Exercise, and Performance Psychology, 10(1), 88-101. Retrieved from https://doi.org/10.1037/spy0000249

Bazyler, C. D., Abbott, H. A., Bellon, C. R., Taber, C. B., \& Stone, M. H. (2015). Strength training for endurance athletes: Theory to practice. Strength and Conditioning Journal, 37(2), 1-12. Retrieved from https://doi.org/10.1519/SSC.0000000000000131

Beneke, R., Leithäuser, R. M., \& Ochentel, O. (2011). Blood Lactate Diagnostics in Exercise Testing and Training. International Journal of Sports Physiology 
https://doi.org/10.1123/ijspp.6.1.8

Carroll, T. J., Taylor, J. L., \& Gandevia, S. C. (2017, May). Recovery of central and peripheral neuromuscular fatigue after exercise. Journal of Applied Physiology. American Physiological Society. Retrieved from https://doi.org/10.1152/japplphysiol.00775.2016

Debold, E. P. (2012). Recent Insights into Muscle Fatigue at the Cross-Bridge Level. Frontiers in Physiology, 3. Retrieved from https://doi.org/10.3389/fphys.2012.00151

Flora, R. (2015). Pengaruh Latihan Fisik Anaerobik Terhadap Kadar Laktat Plasma dan Kadar Laktat Jaringan Otot Jantung Tikus Wistar Effect Anaerobic Exercise on The Blood Lactate Levels and Myocardium Levels in Wistar Rats. Biomedical Journal of Indonesia, 1, 40-42.

Giriwijoyo, S. (2017). Fisiologi Kerja dan Olahraga 'Fungsi Tubuh Manusia pada Kerja dan Olahraga' (1st ed.). Jakarta: Rajawali Pers.

Gorostiaga, E. M., Navarro-Amézqueta, I., Calbet, J. A. L., Hellsten, Y., Cusso, R., Guerrero, M., ... Izquierdo, M. (2012). Energy Metabolism during Repeated Sets of Leg Press Exercise Leading to Failure or Not. PLoS ONE, 7(7), e40621. Retrieved from https://doi.org/10.1371/journal.pone.0040621

Hendra Hasibuan, M., \& H. Jutalo, Y. (2020). Pengaruh Sport Massage Terhadap Penurunan Kadar Asam Laktat Pada Kop Sepak Bola Universitas Negeri Jakarta. Jurnal Ilmiah Sport Coaching and Education, 4(1), 37-42. Retrieved from https://doi.org/10.21009/jsce.04106

Ishii, H., \& Nishida, Y. (2013). Effect of Lactate Accumulation during Exerciseinduced Muscle Fatigue on the Sensorimotor Cortex. Journal of Physical Therapy Science, 25(12), 1637-1642. Retrieved from https://doi.org/10.1589/jpts.25.1637

Jougla, A., Micallef, J. P., \& Mottet, D. (2010). Effects of active vs. passive recovery on repeated rugby-specific exercises. Journal of Science and Medicine in Sport, 13(3), 350-355. Retrieved from https://doi.org/10.1016/j.jsams.2009.04.004

Kaya, I., Kalkavan, A., Senturk, A., Harmanci, H., Karavelioglu, M. B., Yuksel, O., \& Savasli, M. (2013). Analysis of blood lactate and heart rate of indoor sports athletes as a response to various loads. Turkish Journal of Sport and Exercise, 15(3), 86-89. Retrieved from https://doi.org/10.15314/tjse.24306

Ningsih, Y. F., \& Puspitaningrum, D. A. (2018). Efektivitas Stretching Aktif Dan 
Stretching Pasif Dalam Pemulihan Asam Laktat Darah Dan Denyut Jantung Setelah Lari Cepat 400 Meter. Prosiding Seminar Nasional IPTEK Olahraga, (1), 50-54.

Okilanda, A., Dlis, F., Humaid, H., Putra, D. D., Arisman, A., \& Muslimin, M. (2021). Defense Warm-Up Exercise Material for 13-Age Athlete Using Video Technology in Covid-19 Era. International Journal of Human Movement and Sports Sciences, 9(4), 629-634. Retrieved from https://doi.org/10.13189/saj.2021.090404

Rasooli, A. S., Jahromi, K. M., \& Salesi, A. (2012). Influence of massage, active and passive recovery on swimming performance and blood lactate. The Journal of Sports Medicine and Physical Fitness, 147(2), 135-140. Retrieved from https://doi.org/10.13140/RG.2.1.5129.4169

Rusdiana, A. (2020). Fatigue effect on movement kinematic changes of overhead jumping smash in badminton. Jurnal Sportif: Jurnal Penelitian Pembelajaran, 6(2), 272-287. Retrieved from https://doi.org/https://doi.org/10.29407/js_unpgri.vi.14101

Suharjana. (2013). Kebugaran Jasmani. Yogyakarta: Jogja Global Media.

Sukadiyanto, \& Muluk, D. (2011). Pengantar Teori dan Metodologi Melatih Fisik. Bandung: Lubuk Agung.

Syamsudin, F., Herawati, L., Qurnianingsih, E., \& Wungu, C. D. K. (2021). HIIT for Improving Maximal Aerobic Capacity in Adults Sedentary Lifestyle. Halaman Olahraga Nusantara Jurnal Ilmu Keolahragaan, 4(1), 1. Retrieved from https://doi.org/10.31851/hon.v4i1.5139

Todd, J. J. (2014). Lactate: valuable for physical performance and maintenance of brain function during exercise. Bioscience Horizons, 7, hzu001-hzu001. Retrieved from https://doi.org/10.1093/biohorizons/hzu001

Wiltshire, E. V., Poitras, V., Pak, M., Hong, T., Rayner, J., \& Tschakovsky, M. E. (2010). Massage impairs postexercise muscle blood flow and 'lactic Acid' removal. Medicine and Science in Sports and Exercise, 42(6), 1062-1071. Retrieved from https://doi.org/10.1249/MSS.0b013e3181c9214f 